RFP-4517

RFP-4517

June 2, 1992

June 2, 1992

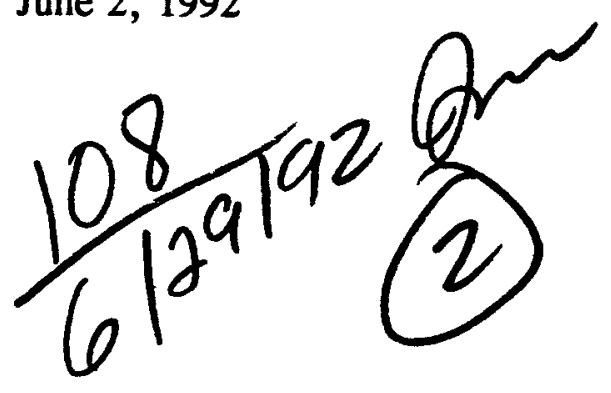

\title{
PLUTONIUM PYROPHORICITY
}

\author{
J. L. Stakebake
}

NEERE ROCKY FLATS

Rocky Flats Plant

P. O. Box 464

Golden, Colorado 80402-0464

DISTRIBUTION OF THIS DCCUMENT IS UNLIMITED

U.S. DEPARTMENT OF ENERGY

CONTRACT DE-AC, 4 -90DE62349 


\section{DISCLAIMER}

This report was prepared as an account of work sponsored by an agency of the United States Government. Neither the United States Government nor any agency thereof, nor any of their employees, makes any warranty, expressed or implied, or assumes any legal liability or responsibility for the accuracy, completeness, or usefulness of any information, apparatus, product, or process disclosed, or represents that its use would not infringe privately owned rights. Reference herein to any specific commercial product, process, or service by trade name, trademark, manufacturer, or otherwise, does not necessarily constitute or imply its endorsement, recommendation, or favoring by the United States Government or any agency thereof. The view and opinions of authors expressed herein do not necessarily state or reflect those of the United States Government or any agency thereof.

This report has been reproduced directly from the best available copy.

Available to DOE and DOE contractors from the Office of Scientific and Technical Information, P. O. Box 62, Oak Ridge, TN 37831; prices available from (615) 576-8401, FTS 626-8401.

Available to the public from the National Technical Information Service, U.S. Department of Commerce, 5285 Port Royal Rd., Springfield, VA 22161. 


\section{DISCLAIMER}

This report was prepared as an account of work sponsored by an agency of the United States Government. Neither the United States Government nor any agency Thereof, nor any of their employees, makes any warranty, express or implied, or assumes any legal liability or responsibility for the accuracy, completeness, or usefulness of any information, apparatus, product, or process disclosed, or represents that its use would not infringe privately owned rights. Reference herein to any specific commercial product, process, or service by trade name, trademark, manufacturer, or otherwise does not necessarily constitute or imply its endorsement, recommendation, or favoring by the United States Government or any agency thereof. The views and opinions of authors expressed herein do not necessarily state or reflect those of the United States Government or any agency thereof. 


\section{DISCLAIMER}

Portions of this document may be illegible in electronic image products. Images are produced from the best available original document. 
RFP-4517

June 2, 1992
RFP-4517

UC-704 MATERIALS

DOE/OSTI-4500 (Rev. 75)

RFP- -4517

DE92 015650

\title{
PLUTONIUM PYROPHORICITY
}

\author{
J. L. Stakebake
}

SUBJECT DESCRIPTORS

Metal Burning

Plutonium Burning

Plutonium Ignition

Plutonium Oxidation

EG\&G ROCKY FLATS, INC.

ROCKY FLATS PLANT

P. O. BOX 464

GOLDEN, COLORADO 80402-0464

PREPARED UNDER CONTRACT DE-AC04-90DE62349

FOR THE

ALBUOUERQUE OPERATIONS OFFICE

U.S. DEPARTMENT OF ENERGY 
RFP-4517 


\section{CONTENTS}

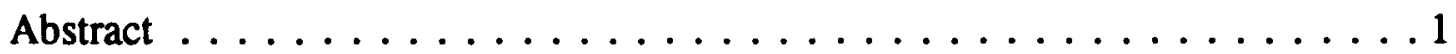

Introduction $\ldots \ldots \ldots \ldots \ldots \ldots \ldots \ldots \ldots \ldots \ldots \ldots \ldots \ldots \ldots \ldots \ldots \ldots$

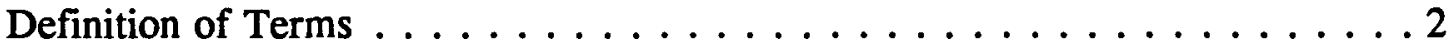

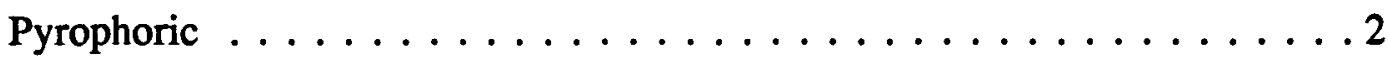

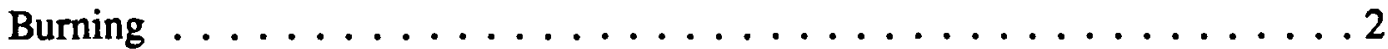

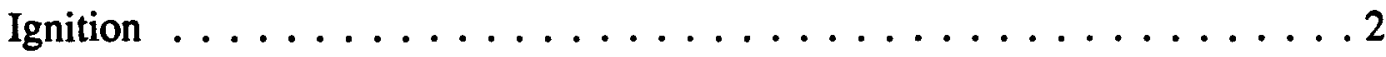

Combustible Material $\ldots \ldots \ldots \ldots \ldots \ldots \ldots \ldots \ldots \ldots \ldots$

Flammable Material $\ldots \ldots \ldots \ldots \ldots \ldots \ldots \ldots \ldots \ldots \ldots \ldots \ldots \ldots$

Explosible Material $\ldots \ldots \ldots \ldots \ldots \ldots \ldots \ldots \ldots \ldots \ldots$

Characterization of Plutonium Ignition $\ldots \ldots \ldots \ldots \ldots \ldots \ldots$

Experimental Factors Affecting Ignition Temperatures $\ldots \ldots \ldots \ldots \ldots$

Material Chemistry Effects on Ignition Temperatures $\ldots \ldots \ldots \ldots$

Environmental Effects on Plutonium Ignition $\ldots \ldots \ldots \ldots \ldots$

Physical Effects on Plutonium Ignition $\ldots \ldots \ldots \ldots \ldots \ldots$

Plutonium Explosibility $\ldots \ldots \ldots \ldots \ldots \ldots \ldots \ldots \ldots \ldots \ldots \ldots \ldots \ldots$

Summary and Conclusions $\ldots \ldots \ldots \ldots \ldots \ldots \ldots \ldots \ldots \ldots \ldots \ldots$

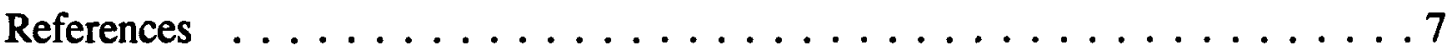


RFP-4517 


\title{
PLUTONIUM PYROPHORICITY
}

\author{
J. L. Stakebake
}

\section{ABSTRACT}

A review of the published literature on ignition and burning of plutonium metal was conducted in order to better define the characteristics of pyrophoric plutonium. The major parameter affecting ignition is the surface area/mass ratio of the sample. Based on this parameter, plutonium metal can be classified into four categories: (1) bulk metal, (2) film and foils, (3) chips and turnings, and (4) powder. Other parameters that can alter the ignition of the metal include experimental, chemical, physical, and environmental effects. These effects are reviewed in this report. It was concluded from this review that pyrophoric plutonium can be conservatively defined as: Plutonium metal that will ignite spontaneously in air at a temperature of $150^{\circ} \mathrm{C}$ or below in the absence of external heat, shock, or friction. The $150{ }^{\circ} \mathrm{C}$ temperature was used to compensate for the self-heating of plutonium metal. For a practical definition of whether any given metal is pyrophoric, all of the factors affecting ignition must be considered.

\section{INTRODUCTION}

Rocky Flats does not have a specific definition for pyrophoric material. In fact, this term is used quite loosely to characterize a number of materials that may be flammable but not pyrophoric and those that are flammable under vastly different conditions. Before one can understand and define pyrophoricity as it applies to plutonium, the broad range of chemical reactions involved in so-called "burning" processes must be understood.

Metal fires, like those of more common combustible solids and liquids (such as wood, paper, plastics, and gasoline), release significant quantities of heat. However, there are some important differences between the mechanisms of burning metal and burning combustibles. Bulk metal is usually more difficult to ignite than the more common organic materials. The ignition of a 1-kg plutonium button requires heating 50-60 seconds with a welding torch. Spread of the burning reaction to cover the button may take 10-15 minutes with the temperature reaching over $800^{\circ} \mathrm{C}$. Paper or gasoline, on the other hand, can be ignited by a spark, and the temperatures rarely exceed $500{ }^{\circ} \mathrm{C}$.

The ignition of reactive metals is due to rapid surface oxidation. The ignition of solid combustibles is usually due to pyrolysis. Surface oxidation is like rusting of iron, and there is a limited area where the process can occur. Pyrolysis involves the thermochemical breakdown of the material and the release of combustible gases such as hydrogen and methane, which can then ignite. The difference between surface oxidation and pyrolysis also accounts for the different appearance of metal fires. Burning metal appears very bright, and the fire appears at the metal surface like the glowing of charcoal. The burning of a solid combustible or liquid is seen in the flame front, usually some distance from the surface.

The difference between surface oxidation and pyrolysis also accounts for the higher temperatures usually observed when metals burn. Burning plutonium is an exothermic reaction in which $1 \mathrm{kcal}$ of heat is released per gram of plutonium. This heat is either deposited in the metal and oxide or released to the environment. As the temperature of the metal increases, its oxidation rate increases exponentially, releasing more heat.

The equilibrium temperature at which plutonium burns depends on a balance between heat generation and heat dissipation. Heat generation is controlled by factors that control the oxidation 
rate, such as oxygen availability and temperature. Heat dissipation is controlled by normal heat transfer mechanisms, such as conduction, convection, and radiation. In comparison, the burning temperature of combustibles is determined by the rate at which combustible gases are formed and diffuse through the solid.

\section{DEFINITION OF TERMS}

\section{Pyrophoric}

The Chemical Dictionary ${ }^{1}$ defines a "pyrophoric substance" as one that will ignite in air at or below room temperature in the absence of added heat, shock, or friction. "Pyrophoric materials" are defined by the DOE as those materials that may ignite spontaneously under the ambient conditions of shipment or storage. ${ }^{2}$

This concept of pyrophoricity appears to be one that is generally accepted by industry and government standards. In the nuclear industry, where self-heating of materials due to radiolytic decay may be involved, a modified definition is probably warranted. Following is a conservative definition of pyrophoric plutonium as used in this paper and currently applied to characterize plutonium at Rocky Flats:

Plutonium metal that will ignite spontaneously in air at a temperature of $150^{\circ} \mathrm{C}\left(302{ }^{\circ} \mathrm{F}\right)$ or below in the absence of external heat, shock, or friction.

Note: $150^{\circ} \mathrm{C}$ is approximately two times the temperature expected to be generated by the self-heating of $1000 \mathrm{~g}$ of plutonium stored in a closed container.

\section{Burning}

A self-sustained process of rapid oxidation or combustion of a material with the liberation of heat.

\section{Ignition}

The act of initiating a burning process. Ignition can occur when the heat of production from the oxidation process exceeds the heat loss to the surroundings.

\section{Combustible Material}

Any material capable of undergoing a chemical oxidation (burning) process with the evolution of heat.

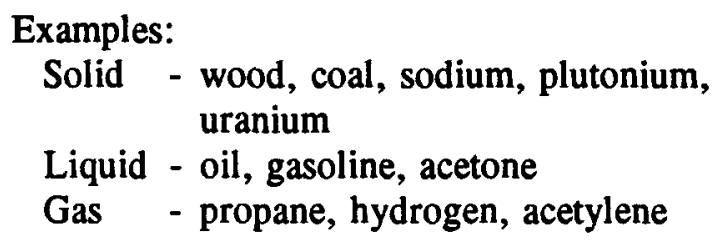

Note: For regulatory purposes, combustible liquids have flash points above $100^{\circ} \mathrm{F}$; therefore, oil would be combustible while gasoline and acetone are flammable.

\section{Flammable Material}

A category of combustible materials that will ignite easily and burn rapidly. Flammable liquids generally have a flash point less than $100^{\circ} \mathrm{F}$. Flammable solids include those that ignite spontaneously or have low ignition temperatures.

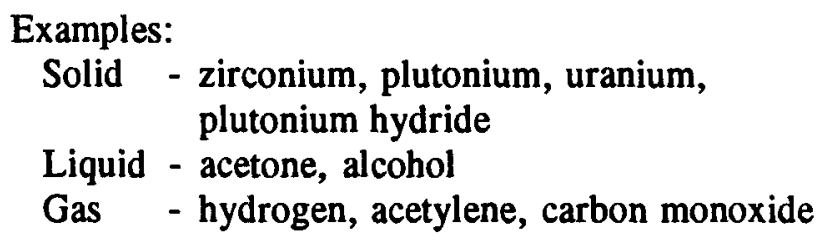

\section{Explosible Material}

Material capable of undergoing a rapid chemical reaction with the production of heat and violent expansion of gases or capable of bursting violently as a result of pressure within the material. 


\author{
Examples: \\ uranium powder \\ plutonium powder \\ plutonium hydride
}

\section{CHARACTERIZATION OF PLUTONIUM IGNITION}

\section{Experimental Factors Affecting Ignition Temperatures}

Ignition measurements are a kind of thermal analysis originally used by Fassel $e t$ al. ${ }^{3}$ for magnesium alloys. Two techniques have been used to investigate plutonium ignition. The first is the burning-curve method in which the sample is heated at a linear rate in the test atmosphere. ${ }^{4,5}$ The second technique, called the shielded ignition method, is less common and excludes the test gas until the sample reaches the desired temperature. ${ }^{5}$

Measured ignition temperatures vary with the experimental parameters. Such experimental parameters as heating rate, sample preheating, and sample size or geometry can influence the measured ignition temperature.

Pitts ${ }^{4}$ found that ignition temperatures decreased as much as $100^{\circ} \mathrm{C}$ when the heating rate was decreased from $50^{\circ} \mathrm{C} / \mathrm{min}$ to less than $5^{\circ} \mathrm{C} / \mathrm{min}$. Above about $10^{\circ} \mathrm{C} / \mathrm{min}$, the heating rate has little effect on ignition temperatures. Most of the results reported for plutonium were obtained using heating rates greater than $10^{\circ} \mathrm{C} / \mathrm{min}$. Therefore, the heating rate effect may generally be discounted when comparing results from various workers.

When samples are preheated under vacuum or in an inert gas, as in the shielded ignition method, the ignition temperature may be reduced. The cause of this is discussed later. Sample sizes used for ignition studies vary, and this produces a wide range of ignition temperatures. This surface area effect is the most significant factor influencing ignition and also is reviewed later.

\section{Material Chemistry Effects on Ignition Temperatures}

\section{Alloying Effects on Ignition}

Schnizlein and Fischer ${ }^{5}$ investigated the effect on plutonium ignition resulting from the addition of different alloying elements. Depending on the material added, the ignition temperature of plutonium could either be raised or lowered. Adding 2 at. $\%$ gallium increased the ignition temperature about $30^{\circ} \mathrm{C}$. Musgrave ${ }^{6}$ compared the ignition of plutonium and plutonium- 1 wt $\%$ gallium coupons and also found this alloy to ignite at temperatures about $30-40{ }^{\circ} \mathrm{C}$ higher than unalloyed plutonium. On the other hand, addition of cobalt and nickel lowered the ignition temperature $30-40{ }^{\circ} \mathrm{C} .^{7}$ This behavior is understandable and predictable from a review of the oxidation characteristics of plutonium. Unalloyed plutonium and some alloys oxidize much faster and with more spallation than the plutonium/gallium alloy. The higher the oxidation rate, the lower the ignition temperature of the sample.

\section{Surface Oxide Effects on Ignition}

Plutonium is very reactive in air and forms plutonium dioxide $\left(\mathrm{PuO}_{2}\right)$, plutonium sesquioxide $\left(\mathrm{Pu}_{2} \mathrm{O}_{3}\right)$, and a plutonium oxycarbide (PuOC) under various conditions. Plutonium dioxide retards further oxidation until oxide spallation begins. This effect was seen in the ignition of alloyed plutonium lathe turnings. Turnings stored in air for 14 days had an ignition temperature $30{ }^{\circ} \mathrm{C}$ higher than fresh turnings. ${ }^{4}$

The other plutonium oxides, $\mathrm{Pu}_{2} \mathrm{O}_{3}$ and $\mathrm{PuOC}$, are formed at higher temperatures when a $\mathrm{PuO}_{2}$ film on plutonium is heated in vacuum or in an inert atmosphere. Such a condition exists when the shielded ignition method is used. Alloyed plutonium coupons containing a PuOC coating were found to ignite at temperatures $100-200^{\circ} \mathrm{C}$ lower than clean plutonium. ${ }^{4}$ Removal of the 
PuOC layer restored the original ignition temperatures. This effect is difficult to evaluate effectively because of the different amounts and types of oxide present.

\section{Surface Hydride Effects on Ignition}

Water vapor in the air environment is known to accelerate oxidation. Plutonium coupons stored in humidities between 1 and $60 \%$ for up to eight weeks exhibited only slight decrease in ignition temperatures. However, when unalloyed plutonium lathe turnings were stored in these environments, ignition temperatures decreased about $100{ }^{\circ} \mathrm{C} .{ }^{6}$ This was attributed to the severe oxidation and disintegration of the turnings. Alloyed plutonium lathe turnings contain an adherent oxide, and ignition temperature increased slightly due to the protective nature of the oxide. The reaction of plutonium with water produces an oxide/hydride product that can ignite in air. Heat generated by this product ignition could be sufficient to ignite high surface area plutonium. Thus, plutonium that normally would not be pyrophoric may be ignited by the burning of a pyrophoric corrosion product.

\section{Environmental Effects on Plutonium Ignition}

\section{Oxygen Concentration Effects on Ignition}

One way to eliminate ignition is to remove the oxygen from the environment. Musgrave ${ }^{6}$ studied the effect of oxygen concentration on the ignition of alloyed plutonium coupons, lathe turnings, and 140 -mesh chips. Coupons $\left(0.5 \mathrm{~cm}^{2}\right)$ ignited at 510 ${ }^{\circ} \mathrm{C}$ in 10 and $20 \%$ oxygen, but did not ignite in lower oxygen concentrations. Lathe turnings did not ignite in oxygen concentrations less than $5 \%$ and required a temperature of $400{ }^{\circ} \mathrm{C}$ to ignite in $8 \%$ oxygen. Finally, the plutonium fines did ignite at $170^{\circ} \mathrm{C}$ in oxygen concentrations as low as $3 \%$. Oxygen concentrations above this level had no effect on the ignition temperature.

\section{Solvent Vapor Effects on Ignition}

Plutonium lathe turnings and fines are produced during machining operations and then degreased in carbon tetrachloride. To evaluate any effect solvent vapor might have, a series of ignition tests were carried out in nitrogen containing $<1,3,5$, and $20 \%$ oxygen plus carbon tetrachloride vapor concentrations of 1.5 and $10 \% .^{6}$ Results showed that carbon tetrachloride vapor significantly affects plutonium ignition. The ignition temperature of plutonium lathe turnings in air with $10 \%$ carbon tetrachloride vapor was lowered from 270 to $200{ }^{\circ} \mathrm{C}$. Ignition was also found to occur at $280{ }^{\circ} \mathrm{C}$ in $3 \%$ oxygen plus $10 \%$ solvent vapor. Plutonium turnings did not ignite in $3 \%$ oxygen when carbon tetrachloride vapor was absent. When solvent concentrations were reduced to $1.5 \%$, they had no effect on the ignition temperatures. This was true for both carbon tetrachloride and perchloroethylene. ${ }^{8}$ While the ignition temperature is reduced, burning temperatures and rates are also lowered. Similar effects have been observed for uranium ignition in halogenated hydrocarbons. ${ }^{9}$

\section{Physical Effects on Plutonium Ignition}

\section{Surface Area Effects on Ignition}

The single most significant parameter affecting plutonium ignition is the metal surface area, or more specifically, the surface area/mass ratio. Bulk pieces of plutonium (1-kg button) may require more than a minute of heating with a welding torch to ignite. ${ }^{7}$ On the other extreme, plutonium powder can ignite spontaneously at room temperature when exposed to air.

Figure 1 is a composite summary of plutonium ignition temperatures measured by a number of different workers. ${ }^{4-6,10-14}$ This figure includes data obtained for both alloyed and unalloyed plutonium. Measurements were made in either air or oxygen atmospheres. The impact of these parameters on the ignition temperature is considered minimal 


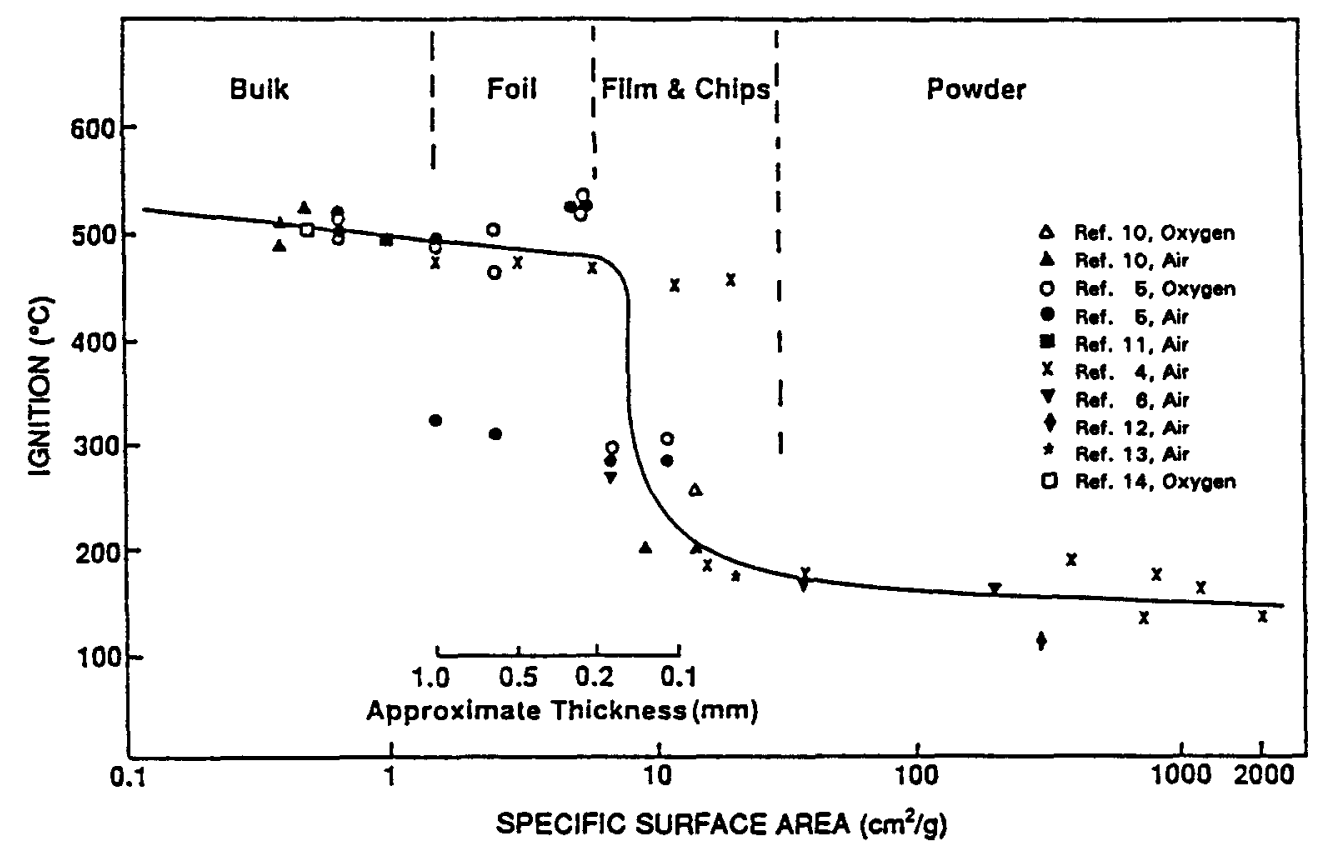

FIGURE 1. Effect of Surface Area on Plutonium Ignition Temperatures

compared to surface area and considering the experimental differences between laboratories.

Ignition temperatures of plutonium fall into two major regimes that depend entirely on the geometry of the sample. The dividing line between the two regimes (Figure 1) occurs at a specific surface area between 10 and $20 \mathrm{~cm}^{2} / \mathrm{g}$. This boundary generally divides bulk samples and foils from lathe turnings and powders.

Samples in the first regime have specific surface areas less than $8 \mathrm{~cm}^{2} / \mathrm{g}$, and their ignition temperatures exceed $450^{\circ} \mathrm{C}$. This category includes coupons ( 3 by $20 \mathrm{~mm}$ ) as thin as about $0.2 \mathrm{~mm}$.

The second regime is made up primarily of plutonium powder and filings with specific surface areas greater than $20 \mathrm{~cm}^{2} / g$. This category also includes material removed from plutonium by wire brushing. Ignition temperatures in this regime vary between 110 and $190^{\circ} \mathrm{C}$. Available experimental data in this region are scattered, but such scatter is not considered excessive or unexpected because of the differing degrees of oxidation for each sample. It is important to note that powder and chips that are free of oxide would be expected to ignite at much lower temperatures than shown in Figure 1.

A transition region exists between the high- and low-temperature regimes. Plutonium classified as "transition" can have ignition temperatures as high as $475^{\circ} \mathrm{C}$ or as low as $175^{\circ} \mathrm{C}$. Predictability of ignition temperatures in this region is very poor. The reason for this is attributed largely to heat transfer, which is strongly influenced by the sample geometry and the amount of plutonium present. Plutonium forms that fall into this category include very thin films, lathe turnings, and chips.

\section{Mechanical Stress Effects on Ignition}

Pitts ${ }^{4}$ investigated the effect of imposing internal stress on a plutonium foil on the subsequent ignition temperature. The ignition temperature was reduced and a pre-ignition exotherm was often present. One concern with the application of mechanical stress is that it creates fractures in the 
protective oxide layer. In addition, it may also create friction and heating of the metal. This combination of effects has resulted in room temperature ignition of lathe turnings that were being briquetted. The stress need not be great if it is sufficient to break the oxide layer. The effect of such an action may be instantaneous (as in the explosion of a hand-held can of chips) or delayed (as in the ignition of a can of chips stored in a glovebox).

\section{Heat Transfer Effects on Ignition}

Plutonium ignition is dependent upon the plutonium being heated above its ignition temperature. The amount of heat absorbed by a plutonium sample is strongly influenced by the heat transfer properties of the plutonium containment materials. Heat transfer can have several positive effects on plutonium ignition and burning.

- Heat transfer away from the plutonium metal will result in higher heat input being required to obtain ignition.

- Heat transfer to high heat capacity materials and away from the plutonium will lower the burning temperature.

- Heat transfer can aid in extinguishing a plutonium fire.

The effect of heat transfer is illustrated by an attempt to ignite an $1800-\mathrm{g}$ ingot on a stainless steel plate. After 15 minutes, the unsuccessful endeavor was discontinued and the ingot was placed on a Transite plate where it ignited in two minutes.?

\section{PLUTONIUM EXPLOSIBILITY}

A large number of metal and metal alloy powders ignite explosively. Uranium and uranium hydride have a severe explosion hazard rating as determined by the U. S. Bureau of Mines. ${ }^{15}$ The powder used for these measurements was in the 3to $10-\mu \mathrm{m}$ range. When dispersed in a cloud at concentrations greater than $1 \mathrm{~g} / \mathrm{ft}^{3}$ or in a surface layer, the material ignited and exploded at $20^{\circ} \mathrm{C}$. The maximum pressure generated from these explosions was in the 40- to 50-psig range. However, the rate of pressure rise was 3400 and $6500 \mathrm{psi} / \mathrm{sec}$ for uranium and uranium hydride, respectively. To prevent ignition, the oxygen concentration in an inert gas had to be less than $2 \%$.

Similar information is not available for plutonium. Nelson, ${ }^{16}$ however, found that submillimeter droplets of a molten plutonium/gallium alloy exploded following ignition. This ignition occurred toward the end of the burning cycle of the droplet. Plutonium powder will usually be oxidized as it is generated in air or low-level oxygen concentrations before an explosive concentration can be reached. If plutonium powder or hydride is generated in an inert (e.g., $100 \mathrm{ppm}$ oxygen) environment and is then suddenly exposed to air, the potential exists for an explosive reaction. Based on Nelson's work, any explosion with plutonium is expected to be less severe than that observed for some other metals.

\section{SUMMARY AND CONCLUSIONS}

The previous discussion describes a number of factors that can affect plutonium ignition temperatures. These factors can be identified and even controlled to a certain extent within a given situation or process to minimize plutonium ignition. Based on the definition of plutonium pyrophoricity, i.e., plutonium that will spontaneously ignite in air below $150^{\circ} \mathrm{C}$, only plutonium powder and fines are considered truly pyrophoric. Practical experience, however, has shown on a number of occasions that plutonium chips and lathe turnings can ignite at room temperature. These materials fall into a transition region shown in Figure 1 where very minor alterations in chemical composition, processing history, and environment can change ignition temperature from $450{ }^{\circ} \mathrm{C}$ to $200^{\circ} \mathrm{C}$ or lower. 
Most incidents of plutonium ignition can be traced to some external influence, such as machining or briquetting along with the presence of oil and carbon tetrachloride. Such operations either generate heat or crush and break the turnings to expose oxide-free surfaces that are susceptible to very rapid oxidation. These experiences emphasize the important role that ignition sources, physical shock, and flammable or reactive contaminants play in plutonium ignition.

Finally, Figure 1 is presented as a summary of data obtained under laboratory conditions. It illustrates only the effect of the surface area/mass ratio on plutonium ignition temperatures. These data may be used only as a guideline in estimating the potential pyrophoricity of a plutonium sample. To more closely assess the potential pyrophoricity of a sample, all other factors that can influence ignition must be carefully considered on a case-by-case basis. In fact, these other factors may have a more determining effect on ignition temperature than the surface area/mass ratio.

\section{REFERENCES}

1. The Condensed Chemical Dictionary, Gassner G. Hawley (Ed), Van Norstrand Reinhold Co., New York, NY, 1977.

2. TRU Waste Acceptance Criteria for the Waste Isolation Pilot Plant, WIPP-DOE-069, Waste Isolation Pilot Plant, Carlsbad, NM, 1991.

3. W. M. Fassel Jr. et al., J. Metals, 3, p 522, 1951.

4. S. H. Pitts, Nuclear Safety, 9, p 112, 1968.

5. J. G. Schnizlein and D. F. Fischer, J. Electrochem. Soc., 115, p 462, 1968.
6. L. E. Musgrave, Effect of Water Vapor, Reduced Oxygen Concentrations, and Solvent Vapors on Plutonium Ignition, RFP-1566, The Dow Chemical Co., Rocky Flats Plant, Golden, CO, 1971.

7. R. E. Felt, Burning and Extinguishing Characteristics of Plutonium Metal Fires, ISO-756, Isochem Inc., Richland, WA, 1967.

8. L. E. Musgrave, "Plutonium Ignition in Perchloroethylene Vapor," RFP-4560, The Dow Chemical Co., Rocky Flats Plant, Golden, CO, 1969.

9. L. Leibowitz, J. G. Schnizlein, and L. W. Mishler, Nucl. Sci. Engr., 15, p 404, 1963.

10. R. F. Carter, B. Foy, and K. Stewart, United Kingdom Report, AERO Conf./8, 1960.

11. E. Dempsey and A. E. Kay, J. Inst. Metals, 86, p 379, 1958.

12. L. E. Musgrave, "Ignition Characteristics of Plutonium Powder," RFP-4566, The Dow Chemical Co., Rocky Flats Plant, Golden, CO, 1971.

13. L. E. Musgrave, "Ignition Characteristics of Plutonium Sputtered Films," RFP-4559, The Dow Chemical Co., Rocky Flats Plant, Golden, CO, 1972.

14. E. J. Chatfield, J. Nucl. Mater., 32, p 218, 1969.

15. M. Jacobson, A. R. Cooper, and H. Nagy, Explosibility of Metal Powders, R.I. 6516, U. S. Bureau of Mines Report of Investigation, 1964.

16. L. S. Nelson, High Temperature Science, 12, p 297, 1980. 
RFP-4517 